\title{
Gold Country: the politics of landscape in exurban El Dorado County, California
}

\author{
Craig Beebe and Stephen M. Wheeler ${ }^{1}$ \\ University of California at Davis, USA
}

\section{Introduction}

The landscapes of exurbia - low-density semi-rural areas usually at the outskirts of metropolitan regions - have seen increasing conflicts between environment and development and frequently have enviropolitical contexts that make effective planning difficult. In the USA, residential growth is rapid in many such areas due to their amenity value. It frequently leads to loss of habitat, native species, wildlife corridors, agricultural land, wilderness, and hydrological function and quality (e.g. Odell et al. 2003; Theobald et al. 1997). Such landscapes tend to have political and social forces strongly promoting continued development, as well as notable property rights movements. Thus it is challenging for positive planning sentiments, politics, and institutions to arise so as to better manage growth, protect habitats, and pursue sustainable housing and transportation patterns.

A starting point is to understand how the political ecology of exurban jurisdictions affects local planning, and in this article we explore these dynamics in one rapidly growing exurban jurisdiction: El Dorado County, California, on the eastern fringes of the Sacramento metropolitan region. We consider how different ideas of landscape - as a source of resources and wealth, as an isolated rural retreat, as a vital natural habitat, and as an 'upscale' enclave - have met in this setting, primarily from the 1980s onwards, leading to political conflict over how the landscape should look and who it should accommodate. Concerned residents in the County have responded to continued development with increasingly reactive measures to try to control its future. A strong landowner-rights culture, some of it promoted by these same residents, has worked against sound planning solutions, and has consistently undercut government institutions and planning itself. In this context, different actors have utilized shifting tools of power to assert their authority over the landscape's appearance and governance, often in a manner that has significantly weakened governance and contributed to a continued degradation of the landscape's ecological integrity. Furthermore, as we show, conflicts over the exurban landscape have largely ignored the political economy and the broader social, ecological context, as well as overlooking less powerful populations and ecologies within its jurisdiction. This leaves a complex challenge for those who would seek more proactive planning in an exurban setting like El Dorado County. We explore some potential directions for future planning in our conclusion, including developing stronger local planning mechanisms, developing more collaborative planning, better articulation of alternative growth models, and strengthened state and regional planning frameworks.

\section{Setting and method}

El Dorado County is central to the history of California, being the site of Sutter's Mill and the beginning of the 1849 Gold Rush. Located on the western slopes of the Sierra Nevada mountains, it contains scenic canyons and valleys, oak woodlands and ranchland, and picturesque remnants of mining towns. Most residents live toward the western edge of the county, near Sacramento, but county land continues on the other side of Eldorado National Forest into the Lake Tahoe region at the crest of the Sierra. Since the politics, institutions, demographics, and history of the Tahoe area differ substantially from the rest of the county, that region is not considered here.

${ }^{1}$ Craig Beebe, Geography Graduate Group, University of California at Davis, USA. craigwbeebe "at" gmail.com. (Current address: 5908 SE Reedway Street, Portland, OR 97206, USA. Current affiliation: 1000 Friends of Oregon). Stephen M. Wheeler, Associate Professor, Landscape Architecture Program, University of California at Davis, One Shields Ave., Davis, CA 95616, USA. smwheeler "at" ucdavis.edu. Thankyou to 2 referees. 
Due in part to its proximity to Sacramento, which saw substantial growth in the twentieth century, El Dorado County's nineteenth century gold rush was followed by a mid-to-late twentieth century "land rush," and its formerly rural landscapes increasingly feature ranchettes, subdivisions, and newly widened arterial roads. The county's population is still small compared to other California counties, at 181,058 in 2010, but grew over 120 percent between 1980 and 2010. New residents of the county are relatively affluent and lack racial diversity. The county's median household income of \$66,129 was much higher than the California average of $\$ 57,708$ in 2010 . The ethnic makeup is homogenous by California and Sacramento region standards: 86.6 percent of residents are white, compared to 55.7 percent in the Sacramento Metropolitan Area and 57.6 percent in California as a whole. The proportion of Hispanics (counted as "white" by the U.S. Census) is also much lower in El Dorado. Roughly 80 percent of the county lives in single-family detached homes, far higher than the statewide average of 58.3 percent. The county's economy today is heavily dependent on management and professional occupations, services, and sales/office work, which together account for 82.2 percent of the workforce. Many residents work outside the county, indicated by the average commute time of 28.7 minutes, about 87 percent of which is done by private motor vehicle.

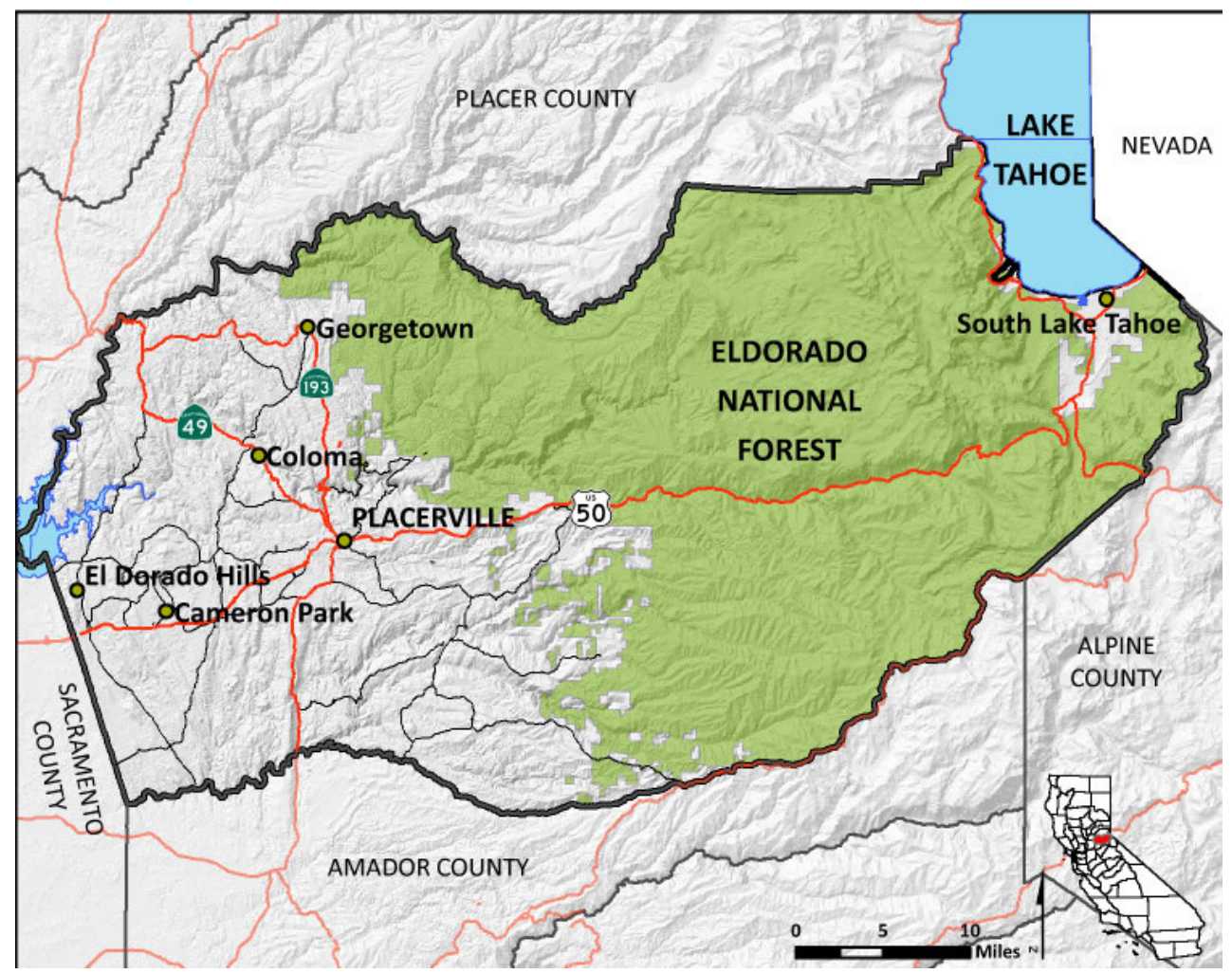

Fig. 1: Context map of El Dorado County. Map by authors.

To develop this case study of exurban political ecology, we employed several methods. We first sought to understand the county's development patterns through intensive GIS analysis of historical growth and built form, using historic maps, aerial photographs, and real estate records. This process was part of a larger effort to understand urban form in the Sacramento region as a whole, described in greater detail elsewhere (Wheeler and Beebe 2011), but produced a detailed mapping of 150 years of land subdivision by 10-year increments within the county, as well as a detailed mapping of built form types. By coding development in both ways (chronologically and by type of form) we were able to understand the variety and distribution of suburban and exurban development forms that exist in the county and when those built landscapes were created. This mapping helps illustrate the high degree to which development has fragmented the county's landscapes (see Figure 3), with detrimental effects on ecosystems, community cohesion, and aesthetic character. 


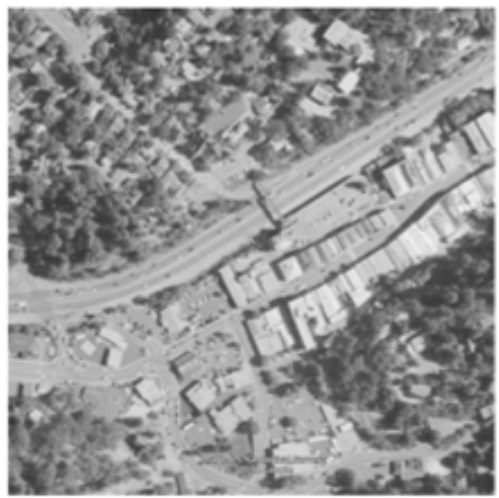

"Quasi-grid," Placerville. Dense mixed-use downtown and nearby residential areas, mostly $19^{\text {th }}$ century. Note $20^{\text {th }}$ century disruptionsHwy 50 freeway, auto-oriented businesses on west end.

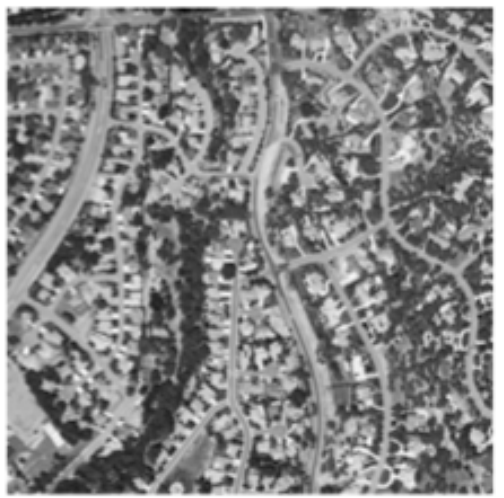

Suburban tract housing, El Dorado Hills. Mostly built during the 1980 s and later.

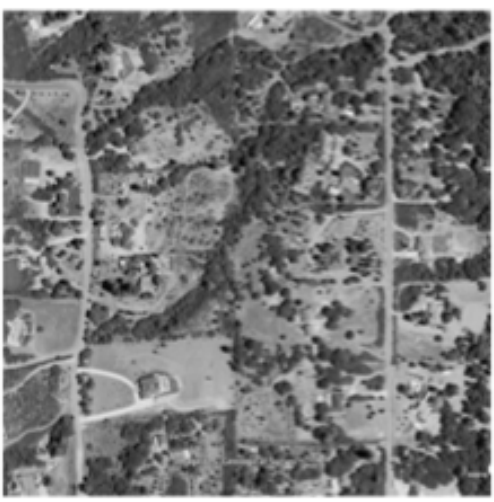

Rural sprawi, central El Dorado County, Note 5-10 acre lots, various housing ages and quality.

Fig. 2: Examples of the built landscape form in El Dorado County at a uniform scale (showing typology used in Wheeler and Beebe 2011).

To understand the county's political and planning history, we then conducted intensive archival research, reviewing planning documents, news articles, histories, real estate records, and other primary sources obtained from local and regional libraries, planning departments, and online sources. This research provided extensive data on planning dynamics from the 1960s through the present.

Lastly, in order to get a firsthand perspective on politics and planning, we conducted semi-structured interviews with 13 local officials, planners, activists, residents, and informed observers. We sought in our

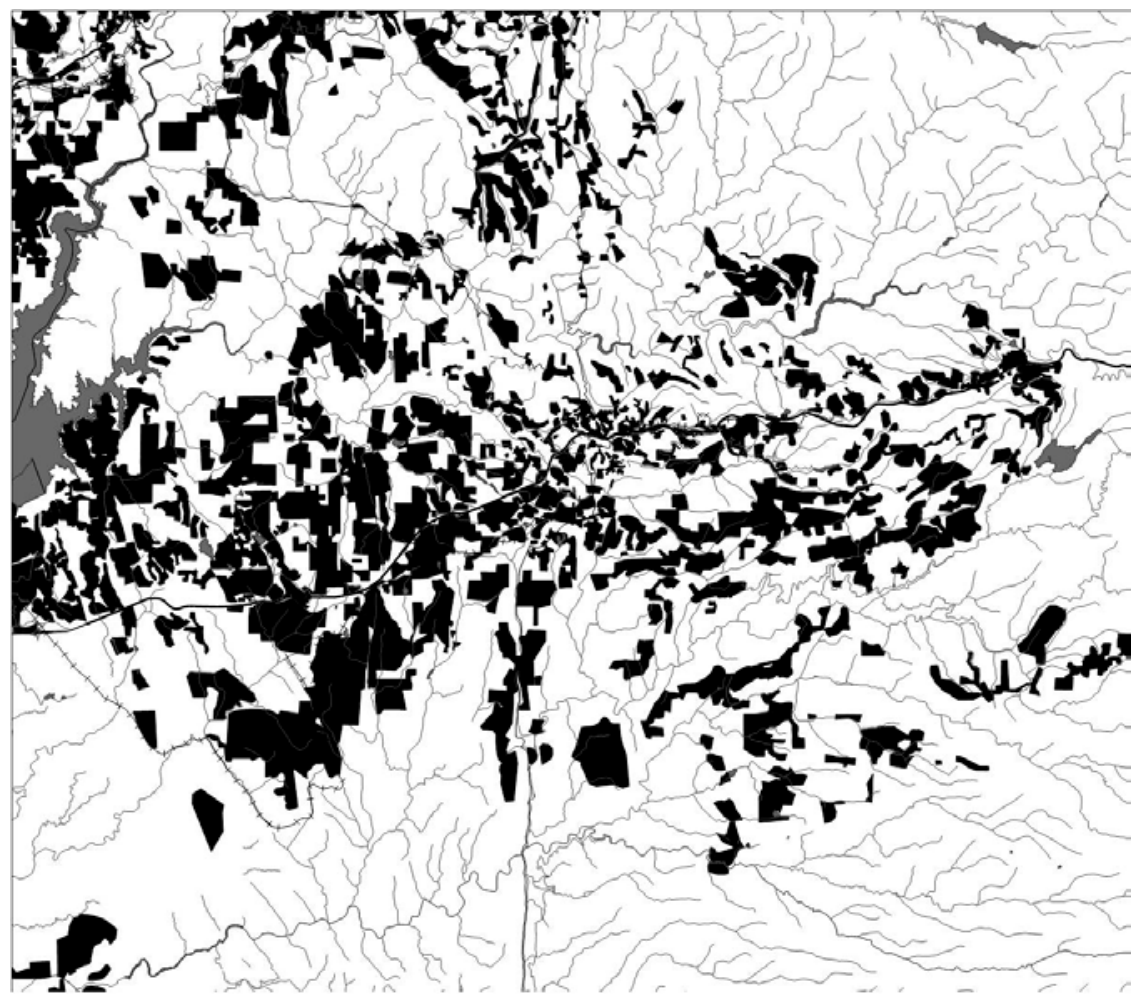

Fig. 3: Development pattern of western El Dorado County, showing the high degree of landscape fragmentation. This figure covers a land area of approximately 30x40 miles (48x64km). Source: Wheeler and Beebe 2011. 
selection to achieve a balance of views and experiences regarding the exurbanization of El Dorado County and its ensuing conflicts, utilizing a snowball method and evidence gleaned from other primary sources to identify potential respondents. Interviews were held with long-time residents, local planners and officials, more recent residents, real estate agents, farmers, and conservationists (though often interviewees fell into more than one category). These interviews, held over the course of five months, were intended to represent a range of perspectives to help us understand what El Dorado County residents, officials, and stakeholders seek for the county's future, and how they interpret the county's history, growth, and identity. In order to protect their identities in the relatively insular world of El Dorado County, we have kept interviewees anonymous in this article.

\section{Literature review: past understandings of Exurbia}

"Exurbia" as it is currently understood-referring to low-density development within rural areas, populated particularly by former residents of urban and suburban regions-has grown rapidly in North American since the middle of the twentieth century. Spectorsky (1955) first coined the term to refer to a collection of elite communities in the vicinity of New York City, located at least an hour away from the city by car and train and featuring large, wooded lots and complex social interactions. Other early views described exurbia as an outer, indefinite ring beyond the more recognizable "suburbs" yet still linked to the central city through commuting and culture (Mumford 1961; Friedmann and Miller 1965). Such exurbs were generally seen as upscale and well-maintained "country estates" (Vance 1972). However, it is now widely recognized that exurbia is considerably more varied in terms of income and appearance, and is often intermingled with other types of rural and suburban land use (e.g., Berube et al. 2006).

Davis and Nelson (1994) and Nelson and Sanchez (1999) both find through quantitative surveys that exurbanites are not substantially dissimilar from suburbanites: white, upper-middle-class, and moderate to conservative politically, although they are more likely to be two-income households and have longer average commute times. Exurbanites appear to get their income primarily from the city, including both downtown and suburban job centers, though some may work from home (Davis and Nelson 1994; Hayden 2003:185; Travis 2007). Other exurbanites are retired, but even these residents are dependent on income earned elsewhere for their livelihoods, transmitted through pension funds, investments, interest payments, and the like (Duane 1999). Exurban residents also include lower-level employees of suburban companies; middle-class residents attracted by relative affordability (Berube et al. 2006; Johnson 2008); and residents whose families have lived in these regions for one or more generations, some of whom continue to be involved in remnant extractive industries and agriculture.

Several studies have employed qualitative research methods to understand what motivates people to migrate to exurbia, and frequently highlight a combination of "push" and "pull" factors, implying that when exurbanites make the decision to move, they are simultaneously attempting to escape one environment and seeking another. For example, Davis and Nelson (1994) find that "desire for space and rural amenities" (a pull factor) and dissatisfaction with suburban environments (a push factor) are both important motivators for exurbanites. Crump (2003) finds that Sonoma County, California, suburbanites are more concerned than exurbanites with easy highway access and with affordability, while exurbanites are more drawn to living in a "rural" environment. Johnson (2008) finds that for Chicago-area exurbanites, privacy and space are more important motivators than nature.

Exurbanites are often consciously rejecting other landscapes. Daniels (1999:26) argues that exurbanites are fleeing both the density of cities and "the sterility of suburbia." Similarly, Halfacree (1997) argues that exurbanites are seeking stable place and meaning in a world they fear is increasingly devoid of either of these. The rural landscape, which is seen as more ordered and predictable, comes to be idealized as a place of history, meaning, and comfort, where one is accepted as part of a community. However, as numerous scholars note in the collection edited by Cloke and Little (1997), such an idealization relies upon and promotes large inequities. Through escalating land and housing prices, lack of new affordable housing, and lack of public transportation, many demographic groups are excluded from participating in the idyll. These include some groups that were previously living there, not to mention working residents and commuters to the area whose whose primary role in the local economy is more service-oriented and generally unconcerned with the "ruralness" such newcomers are seeking. When the idyll is challenged by these "others," conflicts arise over who has the "right" to manage, access, and occupy the exurban landscape.

Exurbia in the USA is best described through a catalog of physical characteristics such as large lot sizes, narrow roads, homes with large setbacks from the street, the frequent presence of barns and other outbuildings, and a lack of sidewalks, curb-and-gutter drainage, and other "urban" features. But exurban forms also vary from place to place. Duane (1999: 212) identifies five levels of development, from singlefamily subdivisions to natural resource lands, that in his view together create exurbia. Planner Tom Daniels (1999: 9), who prefers the term "metropolitan fringe," argues that it is "best thought of not just as a geographic area within a metropolitan region, but also as a step in the development hierarchy between rural areas and a central city." 
Many researchers employ relatively simple quantitative metrics to determine the extent of exurbia. For instance, Brown et al. (2005) employ a measure of exurbia as one unit per one to forty acres, while Clark et al. (2009) favor population densities of 100 to 1,000 people per square mile, and Berube et al. (2006) use, in addition to commuting and growth criteria, a complex density classification based on low-density Census tracts and share of total national housing units, with an average of 2.6 acres per unit. Wheeler (2007) and Wheeler and Beebe (2011) identify "rural sprawl" as subdivision of land into non-agricultural lots of between 1 and 10 acres, accompanied by construction of access roads and other facilities, and this is the primary definition of exurban development used here.

Although different methods produce somewhat different findings of the extent and the nature of exurbia, a few things are clear. First, exurbia in the continental United States now appears at least as extensive as urban areas and suburbs (Berube et al. 2006; Clark et al. 2009; Theobald 2001; Travis 2007). Secondly, this land use is growing quickly in terms of the population it contains and the space it occupies (Berube et al. 2006). Wheeler (2007) finds that exurban development accounted for 57 percent of land development in six sample U.S. metropolitan areas from 1980 to 2005. Third, the impact of exurbia on ecological systems appears to be marked, and includes both direct impacts like habitat destruction and the more indirect effects of road construction and homes "perforating" the landscape (Brown et al. 2005; Odell et al. 2003; Peterson et al. 2008; Theobald 2004; 2005; Theobald et al. 2003). Fourth, exurban development is profoundly changing once-rural communities' appearance, politics, and identity (Hurley and Walker 2004; Travis 2007; Walker and Fortmann 2003; Woods 2006).

Although exurbia has many potential frames of analysis, in this article we draw on a political ecological analysis to explore the landscape politics of El Dorado County. Political ecology, commonly defined as "combin[ing] the concerns of ecology and a broadly defined political economy" (Blaikie and Brookfield 1987:17, cited in Watts and Peet 2004:7; Robbins 2004:6), employs a multi-method approach rooted in several critical traditions and abstract concepts, including cultural ecology, peasant studies, postcolonial studies, feminism, and environmental history (Robbins 2004). Usually this is focused on a particular case study in the developing world. As Paulson et al. (2005) maintain, however, political ecology mobilizes these methods with a clear sense of connecting spaces and scales, recognizing that linkages between scales, particularly the global and local, are manifold and often obscured. Such an approach requires creating chains (or networks) of explanation (Blaikie 1988), that can connect local-level issues with global processes, especially those of neoliberalism as manifest in global capitalism and associated forms of governance. In addition, political ecology calls into question the very discourses that frame our understanding of development, environment, identity, and poverty, among other concepts, revealing how they have been constructed and reproduced by myriad actors, some more powerful than others. Put another way, as Robbins describes it, political ecology focuses on "environmental destruction and construction" (2004:83), and how these forces are created and contested at several scales.

While political ecological analysis is most often applied in the developing world and in rural areas (Robbins 2004), a growing group of geographers and other researchers have demonstrated its usefulness to understanding conflict in urban North America, beginning to answer the call for this type of work by James McCarthy (2002; 2005). Byrne et al. (2007), for instance, employ political ecological analysis to explore the conflicted history of a large park in Los Angeles, while Robbins (2007) uses political ecology as one lens through which to understand the relationship of Americans and their lawns.

Given the definition of exurbia as a blurry boundary region between the dense city and the open wilderness, it seems an especially useful place in which to utilize political ecological analysis. Yet applications have been rare. A very notable exception is geographer Peter Walker who, working with coauthors, has demonstrated the application of this line of inquiry in Nevada County, to the north of El Dorado County and slightly further from the major population and employment centers of the Sacramento region. Walker (2003: 10) has argued that "there is no reason we should not bring political ecology 'home'and...there is every reason to believe that can reveal key dimensions of resource conflicts too often ignored at the expense of continuing conflict, wasted effort, and lost opportunities."

In Nevada County, Walker and coauthors have focused on a bitter struggle over a conservation plan called Natural Heritage 2020 (Hurley and Walker 2004; Walker 2003; Walker and Fortmann 2003; Walker and Hurley 2004). The plan came about following a dramatic shift of power in the county in 1998, in which four environmentalists (all recent migrants) took control of the county Board of Supervisors, which had long been dominated by ranching and timber interests (Duane 1999). Walker and coauthors demonstrate the discursive strategies used by opponents of the new plan, among them charges of socioeconomic elitism (though in reality both sides included people of varied classes), use of biased data, and "eco-extremism." Chief among the accusations was that an "outsider" class was attempting to "impose" a vision of landscape on defenseless "locals." Walker and Fortmann (2003: 486) argue that here the "local" identity is ironic, in part because it was supported by large extractive industries, and in part because "both sides of the struggle over NH 2020 represent advanced forms of capitalism" (emphasis in original). As we will show, similar dynamics are at play in El Dorado County, though we offer a different direction of analysis as to their significance, focusing instead on their implications for planning practice in the exurban context. 


\section{A Gold Rush and then a Land Rush: El Dorado's early planning history}

Like many exurban areas in the western United States, El Dorado County has experienced rapid population growth based on resource exploitation since the beginning of European-American settlement. In 1848 James Marshall, an employee of John Sutter, discovered gold at a sawmill on the South Fork of the American River. Following the discovery, legions of men seeking their fortune invaded the county and the Sierra foothills region (which came to be called the Mother Lode) (Holliday 1981). Almost immediately, subsidiary industries in agriculture, forestry, and trade emerged. Settlers quickly established villages with clearly marked streets, surveyed lots, and even primitive zoning codes (Reps 1979). In contrast to later development, these communities were dense, contained, and mixed-use. The mining boom died relatively quickly, but some towns in the region were able to survive by shifting to other traditional rural economic sectors such as forestry and agriculture, and by virtue of their location along important trade routes. The El Dorado County seat of Placerville, in particular, benefitted from its location on the primary overland route to Nevada and the rest of the nation.

Agriculture and forestry remained strong well into the twentieth century. Though Prohibition halted the booming wine industry, pear and apple orchards replaced many vineyards. Beginning in the 1950s, however, agriculture entered a long decline, in part because Placerville's pear orchards were decimated by pear psylla, an insect-borne parasite and in part due to the success of economies of scale present in larger farms and orchards elsewhere in California (Walker 2004). Ranching families slowly sold out and left the county, the victims of extremely tight margins and competition; only a few major families remain today. Many of the families who left sold property to developers. The timber sector remained solvent until globalization and increasing regulation of federal forests shut down much of the local industry in the late twentieth century. The last local lumber mill closed in 2009 (Swett 1994; Lundstrom 2009).

From 1950 to 2000 the growth in state government, military spending, and related new industries like aeronautical engineering and rocket building, as well as construction of several major freeways, contributed to a massive expansion of the Sacramento region's footprint. The 1960s expansion of U.S. Highway 50 to freeway status provided high-speed connections from El Dorado County to downtown Sacramento and the Bay Area, meaning that employees throughout the region could now live in this rural county and commute with relative ease. Our GIS analysis of historic development shows that exurban subdivision peaked in extent during the 1970s and 1980s, quite likely in response to increased accessibility (see Wheeler and Beebe 2011). Class and racial dynamics may have been at play as well: executives from major corporations such as Aerojet flocked to newly created large-lot subdivisions in El Dorado County, while lower-income workers lived primarily in inner-ring suburbs or in the City of Sacramento. The County Chamber of Commerce vigorously marketed the county's scenery, climate, recreational possibilities, and attractive homes, as well as its racial and economic homogeneity, noting in one brochure that residents of Placerville were "almost one hundred percent American-born" (El Dorado Chamber of Commerce 1946).

Planning regulations developed slowly during these initial decades of rapid residential growth, and were vastly overmatched by pro-development interests. In 1949, the county adopted its first zoning ordinance, and in 1957 it created its planning department (El Dorado County Planning Department 1963). By 1963 planners had zoned about 271,475 acres (out of approximately one million), but politicians had amended the zoning code about 40 times, and the staff complained this created many loopholes in the code (El Dorado County Planning Department 1963:23). Compounding these factors, the county lacked adequate maps and did not hire a mapmaker until the early 1960s. At the time, planners were struggling to complete the county's first General Plan, but made slow progress due to the lack of information or commitments by other agencies. This habit of overworking the Planning Department continues to this day.

From the beginning the county's staff seems to have internalized the belief that it should not challenge an apparently pro-growth status quo. In early 1966, amid the development of its first major subdivisions of "executive housing" at El Dorado Hills and Cameron Park in the far western areas of the county, they published a preliminary version of its first General Plan. This document began with the presumption that growth and development were inevitable. To plan for the projected influx of new residents, less than 30 percent of whom were expected to work in the county by 1985, planners suggested that population areas be "zoned compactly" and that development take place within existing communities, but provided no mechanisms to enforce such visions. Indeed, the plan emphatically states that its policies "will not seek to tell anyone what to do, but...will suggest those things which it would be in the public interest for everyone to do" (Planning Associates 1966: 10). "Public interest," of course, remains undefined; this lack of common definition would fuel later conflicts.

The county's population surged, increasing by 49 percent from 1960 to 1970, and by 96 percent from 1970 to 1980 , when it reached 85,812. With the backing of the mostly pro-development, landowner rightsbased Board of Supervisors, staff approved some 600-700 parcel map subdivisions each year throughout the late 1970s. This boom in population was unregulated. According to one local planner who was one of our respondents, the county "approved [applications] at the counter without any kind of restrictions at all." While many subdivided parcels were never developed because they had poor access and development potential, the 
county was slowly being carved up. During this time the county also allowed "gift deeds" to be recorded, a practice that allows gifts of subdivided parcels to family members without any regulation whatsoever. Often these were "straw arrangements," in which a family member receiving the gift would immediately sell the parcel and give the money back to the first family member. "We had literally thousands of parcels created that way," the planner told us.

Instead of preparing a full General Plan Update in the decades following its bare-bones 1969 plan, as required under state law, the county focused on completing 23 Area Plans for the different sections of the county, which it believed would together constitute its new General Plan (e.g., El Dorado County Planning Department 1977). This piecemeal approach proved woefully inadequate for any sort of countywide vision of land use. With little overall policy for how to direct growth into specific areas of the county, the result was that most areas of the county continued to develop at very low densities. Although the county adopted a Long Range Plan in 1981 as an attempt to reduce the fragmentation of development decision-making, this document did little to rectify the situation because it was subsidiary to the area plans (El Dorado County Planning Department 1981).

The county's pro-growth politics met its first serious challenges in the 1980s, as dwellings multiplied on previously unbuilt landscapes, traffic grew on county roads and US Highway 50, and growth took on a more suburban appearance, particularly in the far western parts of the county (Lambert 1987; 1989). For the first time, some residents began seeking protection of "rural lifestyles" and landscapes, as their ideal of a rural retreat came to be challenged by increasing population and housing. Many residents were also increasingly sophisticated in their use of policy and environmental rhetoric, particularly since many of them were affiliated with state government. Recognizing the changing political dynamics, the inadequacy of its Area Plans, and their potential vulnerability to legal challenge, the County moved to update its General Plan with a countywide land use element.

\section{Matters come to a head: the 1996/2004 General Plan}

The politics of exurban planning in El Dorado County became increasingly heated in the 1990s and 2000s, and culminated in a 14-year battle over a new General Plan that illustrates the nearly intractable nature of recent U.S. exurban political ecology. Different groups of citizens, with dramatically different values and views of the county's identity, as well as different tools and degrees of power at their disposal, fought one another to a standstill for many years. Finally, development resumed with little additional planning guidance. Environmental quality, social equity and the legitimacy of local planning institutions suffered as a result, with little proactive vision emerging.

As growth became more visible in the late 1980s, some concerned citizens threatened lawsuits against the county if it did not adopt a new General Plan as required by state law. In response, the beleaguered Planning Department, which had lost six of fifteen planners in 1989, called for a moratorium on new development until a new Plan could be completed (Terhaar 1989; Vistica 1989; 1990). County supervisors denied this request. The county then hired a highly respected San Francisco-based consultant, Sedway Cooke Associates, to lead the General Plan process. Public workshops were held in communities across the county in 1990 and 1992, and recorded that many residents' primary concern was "protecting rural character" (Moore Iacofano Goltsman 1990; 1992). Sedway Cooke produced a draft that proposed limiting growth to clustered communities and allowing new development primarily in areas that would not threaten "rural" features (Sedway Cooke 1992).

Though this draft had some powerful visions for the county, many county stakeholders viewed it as too complex, insufficiently respectful of the county's context and property rights, and politically unworkable. As in Nevada County (Walker and Fortmann 2003), opponents of the plan employed rhetoric about "outsiders" to derail the project. According to one observer, the "perception was that they had hired a bunch of people from the Bay Area to do planning for a rural county...[the plan's policies] sounded a little too effete and...a bit too much like the Bay Area." Following a contentious 1992 Board of Supervisors election in which three incumbents were voted out and growth was the key issue (Engellenner 1992; Rose 1992), the new Board of Supervisors cancelled Sedway Cooke's contract and directed staff to prepare the Plan in-house.

The resulting second draft also restricted growth, but with fewer specifics. In public hearings on the plan, the response was bitter from all sides of the political spectrum (Engellenner 1993). The Supervisors again demanded a revision, and a third draft further reduced controls on growth. Among other changes, it allowed subdivisions below ten acres in most rural areas; removed prohibitions on developing steep slopes, waterways, and ridge lines; and eliminated mandatory requirements for services, open space, clustering, and affordable housing in planned developments (Bridge 1993a; 1993b; Kinetz 1993). Even this version was not lenient enough for some; as it moved into the environmental review stage the Planning Commission, appointed by the Board of Supervisors, approved many specific requests to change the Plan map, rezoning more than 10,000 acres to allow development generally of the 5-10 acre lot variety (Bridge 1995). Many of these decisions were made with little or no public input, further antagonizing groups seeking growth controls. In January 1996, as a result of harsh criticism from environmentalists, the Board of Supervisors adopted the now vastly weakened plan by a vote of $4-1$. 
Predictably, those seeking to preserve the county's rural landscapes for environmental, amenity, or lifestyle reasons went to court. A controlled-growth group called Taxpayers for Quality Growth along with several other citizen coalitions, neighborhood groups, the Sierra Club, and neighboring Alpine County argued in a 1996 lawsuit that the plan had violated the California Environmental Quality Act by not properly analyzing the impact of growth on traffic and landscape, and by failing to consider alternatives. The Sacramento Superior Court agreed and by rejecting the General Plan's Environmental Impact Report (EIR), prevented the county from approving new development until a new Plan and EIR were complete.

Growth opponents also went to the ballot box in search of a more permanent solution. Anti-growth measures failed narrowly in 1996 and 1998, but while initiatives proposing a simple population cap and seeking to make development conditional on water availability were unable to gain enough support, vehicle traffic ultimately proved to be the issue that would lead El Dorado voters to support restrictions on development. Traffic congestion, a universally disliked element of exurban growth, directly undercut residents' quality of life and sense of living in an isolated rural area far from the concerns of the city. In November 1998 a solid majority of voters approved Measure Y, the Control Traffic Congestion Initiative. This measure required developers to pay 100 percent of road improvements if a project would cause a road to increase to the state's highest road congestion category.

Undeterred, in the early 2000s the Board of Supervisors, following yet another contentious election, again chose the 1996 Plan as the "preferred alternative" for a new EIR with improved analysis. Over continued objections from antigrowth groups the Supervisors adopted the new General Plan and EIR in 2004. The county's development resumed, with the traffic measure providing only a modest constraint on growth.

This contentious, highly antagonistic cycle of litigation and political contest was primarily built on fear of the impacts of growth. It did little to develop any positive vision for future county growth, and nothing towards solutions to the county's social, environmental and political economic challenges. The end result was continued residential growth in low-density, dispersed forms likely to produce the greatest long-run impacts. Environmentalists, however, have seen some signs of progress. One was the 2008 adoption of an Oak Woodlands Management Plan, a document seeking to develop a positive vision of ecological restoration, although environmental groups saw it as too weak, and they litigated unsuccessfully to strengthen it. The second, more promising initiative was to create an Integrated Natural Resources Management Plan. Eventually, proponents hope, this plan will set aside vital areas for wildlife habitat and watershed regeneration. Refreshingly, the discourse that led to these documents focused on promoting environmental sustainability, whereas in the past the El Dorado landscape debate was largely about protecting aesthetics and rural identity against development threats. These efforts represent a more proactive planning approach. However, neither development in planning regulations is likely to move the county far towards sustainability, because neither addresses the fundamental structural and cultural frameworks that have produced exurban El Dorado.

\section{Recurring themes in the landscape politics of El Dorado County}

The story of planning in El Dorado County illustrates a number of themes that appear to characterize exurban areas throughout the United States and that will need to be addressed by planners and researchers in order to better protect landscapes and ecosystems. In particular, the county experienced a transition, in Wood's terms, from "rural politics" to a "politics of the rural" (Wood 2005). While many elected officials espoused the rhetoric of rurality in terms of preserving rural character and lifestyles, in practice they sided with developers seeking to capitalize on that rural ideal by building thousands of homes. Opponents, including some ex-urbanites who had been able to shift their status from "newcomers" to "locals," were driven by feelings of loss, threat, and fear, and asserted their right to protect the landscape by whatever means they saw fit. As elected officials ignored their concerns and visions, these residents found power in crude, reactive mechanisms including litigation and angry outbursts in public meetings. Exurban politics in this county, then, developed into an often-desperate fight to preserve the perceived characteristics of ruralness.

It is important, however, to avoid the simplistic framework used by Duane (1999) in his analysis of Nevada County landscape politics: that of a business-driven, conservative growth machine motivated only by exchange values, opposed by a liberal, consensus-driven citizenry that seems to possess the sole ability to identify "use values." In Duane's eyes, this is a classic "growth machine" scenario (Molotch 1976): a battle between a destructive, profligate Goliath of political conservatives, industry, developers, and local media, serving the needs of selfish escapees from suburbia, and a righteous David, composed of a smaller number of environmentalists. This analysis fails to acknowledge that many environmentalists and slow-growth advocates are themselves exurbanites, or the children of exurbanites, and are responsible for some growth impacts themselves. One of the central paradoxes of the anti-growth sentiment in El Dorado is that the prevention of suburban developments often enables continued piecemeal subdivision and development in the form of rural sprawl, rather than potentially containing this development to specific areas. This is a theme that is often lost in discussions of exurban political struggles.

It is also important to understand the complex sentiments of loss, threat, and fear that run through much of the personal and political dialogue in exurban areas. Exurban residents' anxiety was about "losing" 
landscapes they held dear, sentiments noted by Spectorsky (1955), Marx (1964), and Williams (1973), and in recent studies (e.g. Duncan and Duncan 2004; Kosek 2006). Such feelings are particularly strong among those who have recently moved to a location precisely because of those landscapes. As El Dorado County's growth began to pick up in the 1980s, newspaper articles were full of quotes, including one from a man who had built his "dream home" on five acres in western El Dorado County: "everywhere I look, I'm threatened" (Terhaar 1989). One of our respondents commented that he no longer saw "rolling hills and pastureland, with the lights of Sacramento in the distance." Others spoke of an intangible "quality of life" being diminished by the arrival of newcomers.

Such fears manifested themselves in claims of exclusive possession not only of land, but of the idea of landscape itself, asserting an 'ownership' that is collective but limited to a set of persons never explicitly defined but implicitly understood. This sentiment was seen for example in the campaign slogans of two candidates for Supervisor in June 2010: "Keep Us Rural" and "Preserve Our Rural Lifestyle" (emphasis added). The use of the possessive implies that the "rural lifestyle" is something that belongs solely to existing residents. This exclusivity easily takes on racial and class overtones. One real estate agent we spoke with noted the extent to which exurbanites "want to keep the tribe together." Another interviewee, a local business owner, unfavorably compared denser developments in El Dorado County with "run-down" sections of the Sacramento region inhabited by lower-income people of color. Such attitudes are unsurprising, since they have been part of how El Dorado has been aestheticized and sold by real estate since the 1940s (e.g., El Dorado Chamber of Commerce 1946).

Fear of others often represents itself as a fear of urbanity or 'suburbanity.' These fears can be expressed in reference to a generic, threatening landscape or a specific threatening place, usually somewhere else in California. For example, a Shingle Springs resident, who had moved to the area in 1979, complained to a Sacramento Bee reporter in 1989 that "it's becoming a little suburbia up here." County Commissioner John Wolfenden in 1996 raised the specter of Southern California: "people aren't going to really like this any more than they like Orange County, which is where a lot of people who live here are coming from" (Hoge 1995). Another resident referred to the development of Silicon Valley: "I shudder to think that El Dorado County might become another Santa Clara County within the next 20 years." Raising such specters has proven quite successful at catalyzing opposition to growth, since growth is often conflated with land use planning of any sort.

The local rhetoric is also often grounded in a somewhat defensive nativism. Planning Commissioner Tom Mahach commented in 1993 that the vision of the Sedway Cook Draft General Plan represented "a European approach to land use alien to the American preference for a 'rural lifestyle'" (Bridge 1993a). Mahach later accused county planning staff of trying to keep population growth in "European-style villages surrounded by rural green belts" (Bridge 1995). This viewpoint appears to see the county's landscape as a relatively wild, unregulated expanse free from externally imposed order. Undoubtedly embedded within this attitude is a fear of liberalism, socialism, and multiculturalism. Not surprisingly, today El Dorado County hosts a strong Tea Party movement, which in 2011 pressured the Board of Supervisors to resist participation in federally-funded "Sustainable Communities" regional planning efforts by the Sacramento Area Council of Governments. Opponents spoke of such an arrangement as an abdication of local authority and linked regional planning efforts to the Agenda 21 agreement of the United Nations. One Supervisor who voted against the participation spoke at a public meeting of "losing our identity to regionalization." One of the two supervisors who voted for participating in the studies even defended his vote through a sharply nativist rhetoric. "I fear what they'll do to us if we're not there," he said (Daley 2011).

It is easy to be cynical of such attitudes, but they are often sincerely held, and were voiced repeatedly throughout our interviews and research. The implication is that political ecologists and planners need to commit additional time to understanding how fear and a sense of powerlessness develop and manifest themselves in exurban landscape politics, and indeed in politics generally.

The result of such events, as they have played out through politics, has been a demobilization of planning institutions and processes. From the very establishment of the county's planning department, staff have complained about being overworked and/or insufficiently empowered. Several respondents noted that El Dorado has generally been a place where young planners go for a first job, but where few of them remain for very long. One could argue that the lack of expertise, authority, and funding in the Planning Department is the result of a "rural" county simply misunderstanding the necessity for planning, but the undercutting of local planning structures seems far more systematic than that. Attacks on planners come from all sides. Planning staff are caught in the middle of many different visions for the landscape, with nearly everyone accusing them of conspiracy, idiocy, incompetence, and/or misguidedness. The result, according to several respondents, is that all sides attempt to delegitimize and thus demobilize local planning capabilities, particularly when such capabilities do not seem to be serving their interests. Such demobilization of government is a key feature of turn-of-the-millennium neoliberalism in general, which emphasizes a reduction in the role of the state in regulating society (Larner 2003; McCarthy 2002; 2005). 


\section{Political ecology and the exurban conundrum}

In most landscape planning conflicts, the issues left undiscussed (such as the impact of global capital and political economy on local societies) are at least as significant as those aired in the open in meetings and in local media. This is especially true in exurban places like El Dorado County. Broader ecological, geographical, cultural, and political economic contexts prefigure and frame local conflicts, albeit in unseen ways. Planning battles and rhetoric over growth within El Dorado County - at public hearings, in courts, in newspaper editorials and at the ballot box - can thus be seen as local stages for a broader production, a movement of capital and power that acts as playwright and, too often, as director. Beginning with the nineteenth century gold rush, the evolving forces of capital have driven the boom and subsequent decline of the county's resource extraction and agricultural sectors (Brechin 1999; Walker 2004). More recently developers, largely non-local, have extracted amenity and lifestyle values from the county, while shifts in investment and employment patterns over the twentieth century allowed professional and executive workers to push farther out from the city and have given them the wealth to purchase significant tracts of land that once would have been the domain of agriculturalists or the very wealthy.

Further, exurban planning conflicts too often exclude those without an organized voice. These are people without the will or the capacity to organize or utilize the tools of landscape politics, be it electing sympathetic Supervisors, litigating unfavorable decisions, or successfully running a ballot campaign. Some of these individuals are longtime residents, including poorer residents of areas still dependent on agriculture and forestry. Such individuals were mentioned very rarely in our interviews, except in some instances where they were included in discussions of an idealized agricultural lifestyle. Their interests seem hardly represented in the conflicts we have chronicled. Indeed, many interviewees described how potential alliances between antigrowth and agricultural groups were thwarted, largely through mistrust and ideological differences. Progrowth interests exploited this split and were able to keep farmers and environmentalists from reaching a compromise that would strengthen both of their positions.

The lower-income service workers who staff the restaurants, shopping malls and gas stations of El Dorado County, some of whom live in the county and others of whom commute in from elsewhere, are also missing from the majority of our interviews, or in planning documents and press reports. In debates about how the county's landscape "should" look, few participants mentioned the services a community should provide for its residents, particularly those who fall to its margins. This absence is glaring, particularly in the racialized context of landscape "purity" and who "belongs" in the community. While California law requires the county General Plan to include a chapter devoted to housing intended to plan "for the needs of all economic segments of the community", the interests and voices of those who depend on a non-exurban pattern to live and work are largely left out of the public planning discourse.

Another missing element is the health of the land itself, though perhaps to a lesser extent. Despite its seeming inconspicuousness on the ground, exurban development has contributed to significant degradation of habitat, air quality, the availability and quality of water, and numerous other ecological functions in El Dorado County. Yet although there were instances in which anti-growth groups utilized rhetoric about growth affecting the natural environment, this was largely subsidiary to broader arguments about "ruralness", lifestyle and traffic. This was illustrated by the subtitle of the 2004 General Plan: "A plan for managed growth and open roads; a plan for quality neighborhoods and traffic relief." Nowhere does this subtitle identify a role for environmental health or quality.

Most regrettably, in the corrosive political ecological context of El Dorado County, no organization or group of individuals has emerged to offer visions of how the local landscape and population might function together in a harmonious, equitable, and sustainable way. The lack of a comprehensive ecological vision is common to many planning scenarios in California and beyond, even in urban areas (see Ryan et al. 2004 for a discussion of similar dynamics at play in Ventura County and the greater Los Angeles region). But its omission in an exurban context is all the more striking and unfortunate, in part because a place like El Dorado still has significant habitat and an opportunity to preserve the integrity of threatened ecosystems, and in part because the very frames of landscape politics are built on constructed and extremely problematic notions of "ruralness" and amenity. As the ever-blurred boundary of the metropolitan region, exurbia's great potential as a context in which humans might grapple with the balance of development and preservation has largely been missed in the landscape politics of El Dorado County. Thus the opportunity to envision and pursue what we might term an ecologically and socially "post-exurban" future for the county is largely squandered.

\section{Toward a "Post-Exurban" El Dorado County}

The politics of the exurban landscape has played out over decades, in a way that has satisfied no one. The county's trajectory of development has perhaps slowed a bit, but has not been redirected. While antigrowth groups have successfully delayed many large-scale developments, no powerful voice has emerged to argue that landscapes should not be managed primarily for wealth and to serve existing residents. Or, to advocate instead for a holistic vision of ecological sustainability or social equity. Doing so would probably require understanding and responding to the fears that residents hold, in a respectful and even collaborative way (e.g. Healey 2006). 
Ideally, planners would intervene early enough in the process of exurbanization so as to head off the cycles of anger that result from residents feeling powerless in the face of development. They would bring long-term and newer residents together, help all parties become more comfortable with one another, develop shared knowledge and understandings, and undercut oppositional imagery by helping parties focus on underlying concerns (traffic, noise, environmental quality, etc.) rather than perceived villains (developers, environmentalists, people from Orange County). They would frame issues in terms of a variety of perspectives (global, regional, local) to break through provincial nativism, but would do so in a way that keeps the focus on local values, needs, and ideas, so as to avoid the key actors seeing planning alternatives seen as the work of outsiders. They would at the very least make all parties feel heard, and decision-making more transparent, so as to avoid some of the extreme anger and distrust that has arisen in this locale. Planners would also make an explicit effort to reach populations commonly left out of planning discussions.

In such a scenario, planners would also engage private developers in determining the feasibility of a more managed, ecologically sound approach, highlighting examples of development that are marketable but which still respect local and ecological values. Although some developers would have difficulty adapting to such visions, other more innovative designers (whether local or not) could fill the gap. ${ }^{2}$ In El Dorado County, the popular El Dorado Hills Shopping Center (Figure 4), completed in 2009 and designed to resemble the experience and look of an Italian village, demonstrates some local acceptance of mixed-use, walkable neighborhoods. It has many flaws, including the fact that it is only accessible by car, and that because of current zoning standards, residential uses above the center's shops (as would be present in an actual Italian village) were never seriously considered, though faux windows give the impression that residences may be upstairs. Indeed, one respondent, a local planner, laughed aloud when asked whether residential uses had been considered as a possibility. But if the county could employ examples like this shopping center as a way to engage residents and businesspeople in developing a more proactive, inclusive and collaborative debate. Perhaps another vision for the county's future would emerge.

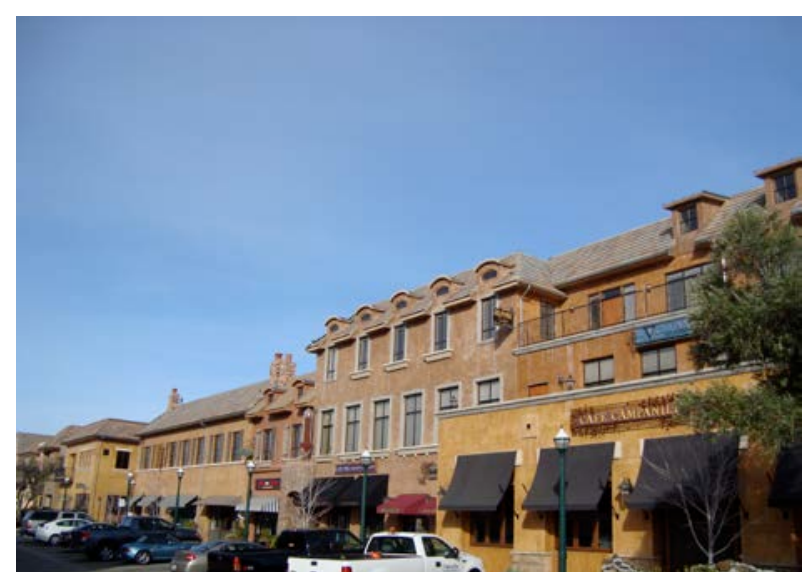

Fig. 4: El Dorado Hills Shopping Center provides some indication of potential support for other models of development in El Dorado County. Photo by Craig Beebe.

Even if enterprising planners had been working in El Dorado County during the period we discuss here, they would probably not have gotten far in attempts to build consensus. The opposing forces were simply too strong, and from all appearances not interested in compromise. The County lay at a confluence of external development pressures, internal conservatism and property-rights-oriented value sets, and weak public sector institutions. It also suffered from a simplistic social discourse that portrays development as a choice between jobs, economic development, and personal freedom on the one hand, and environmental protection, economic stagnation, and government intrusion on the other. In the debates about residential growth, developers argued that only certain types of development would sell, positioning themselves as mere victims of market forces, a position that county elected officials were often too willing to accept. All of these dynamics worked against effective planning, and they will not be easy to change.

If managing growth is nearly impossible within the local political ecological context, a standard approach has been to move to higher levels of government, attempting to use them to leverage local action (Self 1982). Since federal and state governments in the U.S. have generally been disinterested in land use

2 See, for example, the American group of "responsible real estate investors and developers" known as LOCUS, formed by Christopher Leinberger (LOCUS 2012). 
planning questions, this has often meant seeking regional solutions (Daniels 1999: 185; Duane 1999; Wheeler 2000; 2002). This approach may hold some promise for El Dorado County. The County and its cities are members of the Sacramento Area Council of Governments (SACOG), a regional planning body that also includes four other nearby counties. SACOG is well known for having conducted California's first regional Growth Management Blueprint in 2004, a regional vision of smart, compact growth (SACOG 2004). While voluntary for local jurisdictions, the Blueprint has nonetheless been quite influential in shaping the region's growth path. Yet because of the General Plan lawsuit hanging over El Dorado County during the Blueprint's creation, it withdrew from this innovative regional scenario planning process, with only the City of Placerville participating. This missed opportunity was a significant blow for the county, as its General Plan, like so many others, legislates as if the county existed in isolation, and does not explicitly connect its land use decisions to those of neighboring places.

A future regional planning effort in which El Dorado County did participate might be able to create a more inclusive vision outlining how some landscapes might be protected from future growth by concentrating it in other areas. Such regional planning efforts are in fact required under California's 2008 SB 375, legislation that mandates that every region develop a 'Sustainable Communities Strategy' with an integrated transportation, land use, and housing vision shown by computer modeling to be capable of meeting California's GHG reduction targets. However, implementation of SB 375 is still in the early stages. It is not clear what package of incentives and penalties will be developed for enforcement, and there is ample organized resistance to such concepts. This is common in other exurban locations as well. Even in the Portland, Oregon metro region, widely renowned for its regional planning capabilities, political rhetoric in some similar outlying exurban communities on the cusp of more dense development has directly challenged the authority of Metro, the nation's strongest regional planning institution (Walker and Hurley 2011). There has been vocal resistance decrying any type of land use planning as an abrogation of property rights, and even as a global plot seeking to subsume the United States Constitution to global mandates like Agenda 21 (Kaufman and Zernike 2012). Clearly, the challenge to the regulation of growth and its impacts is severe, and only an integrated framework of planning at several higher levels of government-federal, state, and/or regional-is likely to be strong enough to change the planning environment in U.S. exurban locations.

Without a doubt, exurbanization has transformed the American West. Enabled by loose regulations, the creation of roads, reservoirs, power lines, and Internet connections, public desires for "rural" lifestyles, and the ongoing decentralization of jobs, low-density development has spread far into the nation's forests, deserts, and foothills. As we have shown, it has severe and far-reaching impacts on ecologies and political economies.

If places like El Dorado County are to develop in a more sustainable way, a starting point will have to be greater awareness of how city and country have developed together as cultural constructs (Williams 1973), and of the potential directions that this might take in the future. A political ecological analysis, with its attention to interwoven layers of power, nature, capital and class, provides an excellent lens through which to understand how these constructs have contributed to conflict, and to understand the processes of ecological degradation and/or mitigation in a variety of human communities ranging from the urban (e.g. Byrne et al. 2007) to the exurban and rural.

The task now is to translate such analyses into a different path for exurban places. Some future directions have proven frightening to many exurban residents, conjuring up visions of increased road traffic, spreading commercial strips, and estate home landscapes. But more positive visions are also possible, of watershed restoration, preserved open spaces, and more compact, balanced, and diverse human communities. Planners and progressive constituencies will need to do their best to promote engagement around alternative futures that can inspire, rather than frighten and enrage. They will also need increased support from higherlevel governments in order to do this. California will, by all estimates, continue to grow over the next 20 years, but the challenge, as one of our respondents put it, is to "grow with grace." Such a challenge requires respect, dialogue, shared knowledge of how we got where we are, and developing strategies for taking a different path. From such a starting point, we begin to glimpse a post-exurban future for places like El Dorado County.

\section{References}

Berube, A., A.Singer, H.Wilson, and W.H. Frey. 2006. Finding exurbia: America's fastest-growing communities at the metropolitan fringe. Washington, DC: Brookings Institution.

Blaikie, P. and H. Brookfield. 1987. Land degradation and society. London: Methuen.

Brechin, G.A. 1999. Imperial San Francisco: urban power, earthly ruin. Berkeley: University of California Press. 
Bridge, C. 1993a, November 4. El Dorado planners get earful: two views emerge during growth hearing. Sacramento Bee, p. N1.

Bridge, C. 1993b, November 11. Plans to go on '94 ballot: El Dorado board eyes advisory vote on General Plan. Sacramento Bee, p. N1.

Bridge, C. 1995, September 21. Complaints rise on draft General Plan changes. Sacramento Bee, p. N1.

Brown, D.G., K.M. Johnson, T.R. Loveland, and D.M. Theobald. 2005. Rural land-use trends in the coterminous United States 1950-2000. Ecological Applications 15:1851-1863.

Byrne, J., M. Kendrick and D. Sroaf. 2007. The park made of oil: towards a historical political ecology of the Kenneth Han State Recreation Area. Local Environment 12: 153-181.

Clark, J.K., R. McChesney, D.K. Munroe, D.K., and E.G. Irwin. 2009. Spatial characteristics of exurban settlement pattern in the United States. Landscape and Urban Planning 90: 178-188.

Cloke, P. and J. Little. 1997. Contested countryside cultures: Otherness, marginalization, and rurality. New York: Routledge.

Crump, J.R. 2003. Finding a place in the country: Exurban and suburban development in Sonoma County, California. Environment and Behavior, 35: 187-202.

Daley, C. 2011. Supes refuse to participate in regionals study. Mountain Democrat, 16 June.

Daniels, T. 1999. When city and country collide: Managing growth at the metropolitan fringe. Washington, DC: Island Press.

Davis, J.S. and A.C. Nelson. 1994. The new 'burbs: the exurbs and their implications for planning policy. Journal of the American Planning Association 60: 5-60.

Duane, T. 1999. Shaping the Sierra: nature, culture, and conflict in the changing West. Berkeley: University of California Press.

Duncan, J.S. and N. Duncan. 2004. Landscapes of privilege: the politics of the aesthetic in an American suburb. New York: Routledge.

El Dorado County Chamber of Commerce. 1946. El Dorado County, California: History-industry-recreation. Placerville: Old Hangtown Press.

El Dorado County Planning Department. 1963. Six years of planning in El Dorado County. Placerville: El Dorado County.

El Dorado County Planning Department. 1977. Pleasant Valley-Oak Hill-Sly Park area plan and environmental impact report. Placerville: El Dorado County.

El Dorado County Planning Department. 1981. The long range land use plan: A guide to the year 2000. Placerville: El Dorado County.

El Dorado County Planning Department. 2004. El Dorado County General Plan: A plan for managed growth and open roads; a plan for quality neighborhoods and traffic relief. Placerville: El Dorado County.

Engellenner, J. 1992, October 16. Growth emerges as number one issue in 3 El Dorado Supervisor races. Sacramento Bee, p. B1.

Engellenner, J. 1993, July 30. Draft plan for El Dorado's future takes heat. Sacramento Bee, p. B1.

Friedmann, J. and J. Miller. 1965. The urban field. Journal of the American Institute of Planners 31: 312-320.

Halfacree, K.H. 1997. Contrasting roles for the post-productivist countryside: a postmodern perspective on counterurbanization. In P. Cloke \& J. Little (eds.) Contested countryside cultures: otherness, marginalization, and rurality. New York: Routledge. Pp70-93.

Hayden, D. 2003. Building suburbia: green fields and urban growth 1820-2000. New York: Pantheon.

Healey, P. 2006. Collaborative planning: shaping places in fragmented societies. New York: Palgrave Macmillan.

Hoge, P. 1995, December 22. Plan advances in El Dorado-doubles population by 2030. Sacramento Bee, p. B1.

Holliday, J.S. 1981. The world rushed in: the California gold rush experience. New York: Simon \& Schuster.

Hurley, P.T. and P.A. Walker. 2004. Whose vision? Conspiracy theory and land-use planning in Nevada County, California. Environment and Behavior A 36: 1529-1547.

Johnson, B.E. 2008. Nature, affordability, and privacy as motivations for exurban living. Urban Geography 29: 705-723.

Kaufman, L. and K. Zernike. 2012. Activists fight green projects, seeing U.N. plot. The New York Times, 3 February. [Accessed February 20 2012]. www.nytimes.com/2012/02/04/us/activists-fight-green-projectsseeing-un-plot.html

Kinetz, M. 1993, October 24. Supervisors tire of "civil war": board will try to reach truce Tuesday on General Plan process. Sacramento Bee, p. N3. 
Kosek, J. 2006. Understories: the political life of forests in northern New Mexico. Durham: Duke University Press.

Lambert, M. 1987, January 4. Developers are heading for the hills: community in El Dorado faces explosion of new homes. Sacramento Bee, p. A1.

Lambert, M. 1989, March 25. Urban growth crowds rural dreams: El Dorado County residents fear open spaces are disappearing. Sacramento Bee, p. B1.

Larner, W. 2003. Neoliberalism? Environment and Planning D: Society and Space 21: 509-512.

LOCUS: Responsible Real Estate Developers and Investors. 2012. Homepage. [Accessed February 20 2012]. www.smartgrowthamerica.org/locus

Lundstrom, M. 2009, May 3. Sawmill layoffs topple a way of life. Sacramento Bee, p. A1.

Marx, L. 1964. The machine in the garden. New York: Oxford University Press.

McCarthy, J. 2002. First World political ecology: Lessons from the Wise Use movement. Environment and Planning A 34: 1281-1302.

McCarthy, J. 2005. Devolution in the woods: Community forestry as hybrid neoliberalism. Environment and Planning A 37: 995-1014.

Molotch, H. 1976. The city as growth machine: Toward a sociology of place. American Journal of Sociology 82: 309-330.

Moore Iacofano Goltsman. 1990. Summary of comments: Round 1 community workshops; El Dorado County 2010 General Plan. Berkeley: MIG.

Moore Iacofano Goltsman. 1992. Summary of comments: Round III community workshops. Berkeley: MIG.

Mumford, L. 1961. The city in history: its origins, its transformations, and its prospects. New York: Harcourt, Brace \& World.

Nelson, A.C. and T.W. Sanchez, T.W. 1999. Debunking the exurban myth: a comparison of suburban households. Housing Policy Debate 10: 689-709.

Odell, E.A., D.M. Theobald, D.M., and R.L. Knight. 2003. Incorporating ecology into land use planning: the songbird's case for clustered development. Journal of the American Planning Association 69: 72-82.

Paulson, S., L.L. Gezon, and M. Watts. 2005. Politics, ecologies, genealogies. In S. Paulson \& L.L. Gezon (eds.), Political ecology across spaces, scales, and social groups. New Brunswick, N.J.: Rutgers University Press. Pp 17-40.

Peterson, M.N., X. Chen, and J. Lin. 2008. Household location choices: Implications for biodiversity. Conservation Biology 22: 912-921.

Planning Associates. 1966. Summary report: El Dorado County preliminary General Plan. San Francisco: Planning Associates.

Reps, J.W. 1979. Cities of the American West: a history of frontier urban planning. Princeton: Princeton University Press.

Robbins, P. 2004. Political ecology: a critical introduction. Malden, MA: Blackwell.

Robbins, P. 2007. Lawn people: how grasses, weeds, and chemicals make us who we are. Philadelphia: Temple University Press.

Rose, U. 1992, May 24. Growth issue splits District 3 Supervisor candidates. Sacramento Bee, p. N2.

Ryan, C.M., J.P. Wilson and W. Fulton. Living on the edge: growth policy choices for Ventura County. In J. Wolch, M. Pastor and P. Dreier (eds.) Up against the sprawl: public policy and the making of southern California. Minneapolis: University of Minnesota Press. Pp309-342.

Sacramento Area Council of Governments. 2004. Sacramento regional blueprint. Sacramento: SACOG.

Sedway Cooke Associates. 1992. Draft El Dorado County policy framework. San Francisco: Sedway Cooke Associates.

Self, P. 1982. Planning the urban region: a comparative study of policies and organizations. London: George Allen \& Unwin.

Spectorsky, A.C. 1955. The exurbanites. Philadelphia: Lippincott.

Swett, C. 1994, May 7. Sale rescues Camino lumber mill. Sacramento Bee, p. E8.

Terhaar, J. 1989, December 3. El Dorado braces for explosive growth. Sacramento Bee, p. F1.

Theobald, D.M., J.R. Miller and N.T. Hobbs. 1997. Estimating the cumulative effects of development on wildlife habitat. Landscape and Urban Planning 39: 25-36.

Travis, W.R. 2007. New geographies of the American West: land use and the changing patterns of place. Washington, DC: Island Press.

Vance, J.E. 1972. California and the search for the ideal. Annals of the Association of American Geographers 62: 185-210.

Vistica, G. 1989, December 2. El Dorado may hit the brakes on growth for two years. Sacramento Bee, p. B5. 
Vistica G. 1990, January 7. Planning staff growing tired in El Dorado. Sacramento Bee, p. B3.

Walker, P.A. 2003. Reconsidering "regional" political ecologies: toward a political ecology of the rural American West. Progress in Human Geography 27: 7-24.

Walker, P.A. and L. Fortmann. 2003. Whose landscape? A political ecology of the "exurban" Sierra. Cultural Geographies 10: 469-491.

Walker, P.A. and P.T. Hurley. 2004. Collaboration derailed: the politics of "community- based" resource management in Nevada County, California. Society and Natural Resources 17: 735-751.

Walker, P.A. and P.T. Hurley. 2011. Planning paradise: politics and visioning of land use in Oregon. Tucson: University of Arizona Press.

Walker, R.A. 2004. The conquest of bread: 150 years of agribusiness in California. New York: The New Press.

Watts, M. and R. Peet. 2004. Liberating political ecology. In R. Peet and M. Watts (eds.), Liberation ecologies: environment, development, and social movements. New York: Routledge. Pp3-47.

Wheeler, S.M. 2000. Planning for metropolitan sustainability. Journal of Planning Education and Research 20: 133-145.

Wheeler, S.M. 2002. The new regionalism: Key characteristics of an emerging movement. Journal of the American Planning Association 68: 267-278.

Wheeler, S.M. 2007. The evolution of built landscapes in metropolitan regions. Journal of Planning Education and Research 27: 400-416.

Wheeler, S.M. and C.W. Beebe. 2011. The rise of the postmodern metropolis: spatial evolution of the Sacramento metropolitan region. Journal of Urban Design 16: 307-332.

Williams, R. 1973. The country and the city. New York: Oxford University Press.

Woods, M. 2006. Redefining the "rural question": the new 'politics of the rural' and social policy. Social Policy and Administration 40: 579-595.

\begin{abstract}
Low-density exurban landscapes threaten ecosystems and pose challenges for urban and regional planning, especially in nations with relatively weak rural land use regulation like the United States. Growth management efforts in such areas have generally been difficult due to strong pro-development forces and cultures of landowner rights. This article explores the political ecology of planning in one such exurban place, El Dorado County in the Sierra Nevada foothills east of Sacramento, California. Through review of historical documents, news articles, over a dozen interviews with knowledgeable local actors, and GIS analysis of growth patterns, we discuss how a demobilization of local planning develops through dynamics of power, fear, distrust, and antagonism. We explore some possible strategies for developing stronger local planning mechanisms, including more collaborative planning, better articulation of alternative growth models, and strengthened state and regional planning frameworks.
\end{abstract}

Keywords: Exurbia, political ecology, urban planning, landscape, cultural geography, California.

\title{
Résumé
}

Les paysages ex-urbain (périurbains à faible densité) menacer les écosystèmes et posent quelques défis pour la planification urbaine et régionale, en particulier dans les pays ayant la réglementation relativement faible tels que les États-Unis. Des efforts de gestion de la croissance urbain ont généralement été difficile en raison des promoteurs immobiliers, et les droits fonciers. Cet article explore l'écologie politique de la planification dans un endroit exurbaines, El Dorado County dans la Sierra Nevada à l'est de Sacramento, en Californie. Grâce à l'examen de documents historiques, des articles de presse, plus de une douzaine d'interviews avec les experts et les acteurs locaux, et une analyse SIG, nous discutons de la façon dont un programme de démobilisation de la planification locale se développe à travers la dynamique du pouvoir, la peur, la méfiance et l'antagonisme. Nous explorons quelques stratégies pour développer des mécanismes plus solides de la planification locale, y compris la planification plus concertée, une meilleure articulation des modèles de croissance alternatifs, et le renforcement de l'état et les cadres de planification régionale.

Mots-clés: Exurbia, l'écologie politique, urbanisme, paysage, géographie culturelle, Californie. 


\section{Resumen}

Las zonas de baja densidad en barrios periféricos representan una amenaza para los ecosistemas y plantean desafíos para la planificación urbana y regional, en especial en países con una regulación relativamente débil del uso del suelo en zonas rurales, tales como los Estados Unidos. Los esfuerzos por gestionar el crecimiento en estas áreas por lo general han sido difíciles debido a la fortaleza de quienes apoyan el desarrollo y a una cultura que favorece los derechos de los propietarios de tierras. Este artículo explora la ecología política de la planificación de una sola zona periférica de baja densidad, el Condado de El Dorado en las colinas de Sierra Nevada, al este de Sacramento, California. Tras llevar a cabo una revisión de documentos históricos y noticias aparecidas en medios de comunicación, más de una docena de entrevistas con personas de la zona con conocimiento del asunto y un análisis SIG de los patrones de crecimiento, se discute cómo ha tenido lugar una paralización de la planificación local como resultado de dinámicas de poder, miedo, desconfianza y antagonismo. Se exploran algunas de las estrategias posibles para el desarrollo de mecanismos de planificación local más fuertes, entre ellas una planificación más en colaboración, una mejor articulación de los modelos de crecimiento alternativos, y el fortalecimiento de los marcos de planificación regional y estatal.

Palabras clave: barrios periféricos, ecología política, planificación urbana, paisaje, geografía cultural, California. 